\title{
Report of Test Excavations Along FM 3359 in Panola County 41PN3 41PN4
}

Patience Elizabeth Patterson

Follow this and additional works at: https://scholarworks.sfasu.edu/ita

Part of the American Material Culture Commons, Archaeological Anthropology Commons, Environmental Studies Commons, Other American Studies Commons, Other Arts and Humanities Commons, Other History of Art, Architecture, and Archaeology Commons, and the United States History Commons

Tell us how this article helped you.

This Article is brought to you for free and open access by the Center for Regional Heritage Research at SFA ScholarWorks. It has been accepted for inclusion in Index of Texas Archaeology: Open Access Gray Literature from the Lone Star State by an authorized editor of SFA ScholarWorks. For more information, please contact cdsscholarworks@sfasu.edu. 


\section{Report of Test Excavations Along FM 3359 in Panola County 41PN3 41PN4}

\section{Licensing Statement}

This is a work produced for the Texas Department of Transportation (TxDOT) by the report producer. TxDOT and the report producer jointly own all rights, title, and interest in and to all intellectual property developed under TXDOT's contract with the report producer. The report may be cited and brief passages from this publication may be reproduced without permission provided that credit is given to both TxDOT and the report producer. Permission to reprint an entire chapter, section, figures or tables must be obtained in advance from either the Supervisor of the Archeological Studies Branch, Environmental Affairs Division, Texas Department of Transportation, 125 East 11th Street, Austin, Texas, 78701 or from the report producer. 


\section{REPORT OF TEST EXCAVATIONS \\ ALONG FM 3359 IN PANOLA COUNTY \\ 41 PN 3 \\ 41 PN 4}


INITIAL TESTING REPORT AND RECOMMENDATIONS

FOR ARCHEOLOGICAL RESOURCES ALONG PROPOSED

F.M. 3359, PANOLA COUNTY TEXAS

Patience Elizabeth Patterson

State Department of Highways

and Public Transportation

Archaeology Section 


\section{INTRODUCTION}

Project Background

The archeological testing at sites 41PN3 and 41PN4 reported herein, came about as a result of discovery of these sites during an archeological reconnaissance of the proposed right of way on FM 3359 near Deadwood in Panola County, Texas (Figure 1). Reporting and preliminary testing of these sites was completed so as to be in compliance with Public Law 89-670 (The Department of Transportation Act of 1966), 36 CFR 60, 36 CFR 800, and the Memorandum of Understanding between the State Department of Highways and Public Transportation and the Texas Antiquities Committee, dated January 5, 1972.

Both sites were discovered by members of the staff of the Archeology Section of the Design Division of the State Department of Highways and Public Transportation. Surface reconnaissance of the area produced 8 plain pot sherds, a few flakes and sandstone fragments from 41PN3 and one broken biface and a few flakes at 41PN4. No shovel tests were conducted during the reconnaissance,

Preliminary testing of the two sites was conducted by an archeological crew of three persons from July 11 through July 20, 1978. This Initial investigation was implemented to provide information allowing assessment of the cultural resources to be affected, to formulate a plan for mitigation, and to assess the two sites as to their eligibility for inclusion within the National Register of Historic Places.

\section{Setting}

Sites 41PN3 and 41PN4 are located in the southeast portion of Panola

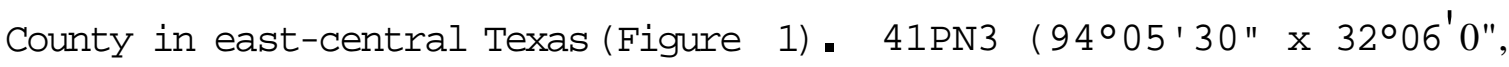


This Page Redacted Per THC Policy 
USGS 15' Deadwood Quadrangle) is a small terrace. site located 780 feet northwest of Mill Creek (Figure 2). The proposed new right of way for F.M. 3359 is situated from 1.6 miles southeast of F.M. 2517 to 0.1 miles

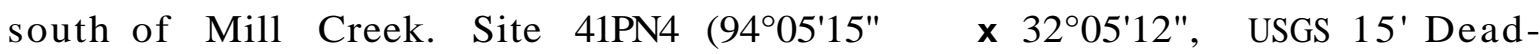
wood Quadrangle) is located on a bluff on the east side of Mill Creek. approximately 300 feet upstream from the existing county road crossing and about 825 feet southeast of 41PN3 (Figure 3).

Physiographically, the study area is situated in the West Gulf Coast section of the Coastal Plain Province (Fenneman 1938:106). The area is characterized by a flat to rolling landscape; i.e., with large, nearly level, moundy areas occuring on terraces adjacent to larger areas on bottom lands (SCS 1975:1). Mantachie series of soils is found in the study area along with the Cart-Erno complex, Both series of soils were formed in alluvial sediments having been, in some cases, reworked by wind. The parent material in which these soils form is the Wilcox Group, of Eocene age. Pleistocene and Holocene age alluvium occur along river and stream terraces in the area(SCS 1975:51-53). These are, in most cases, fine, sandy and clay loams. This landscape sustains watertolerant hardwoods (in flood prone areas), conifers, and grasses. Vines and shrubs quickly grow in open areas and plant competition is severe (SCS 1975: 9-16). All the biota fall within the Austroriparian Biotic Province. An enumeration of flora and fauna can be found in Blair (1950: 98-100) and numerous publications regarding archeological sites within the sane biotic province (see, for example, Clark and Ivey N.D.; McDonald 1972 and McClurkan et a I 1966).

The study area is in what Carr (1967:5) refers to as "East Texas", one of three climatic regions, and one of 10 climatic subdivisions of 


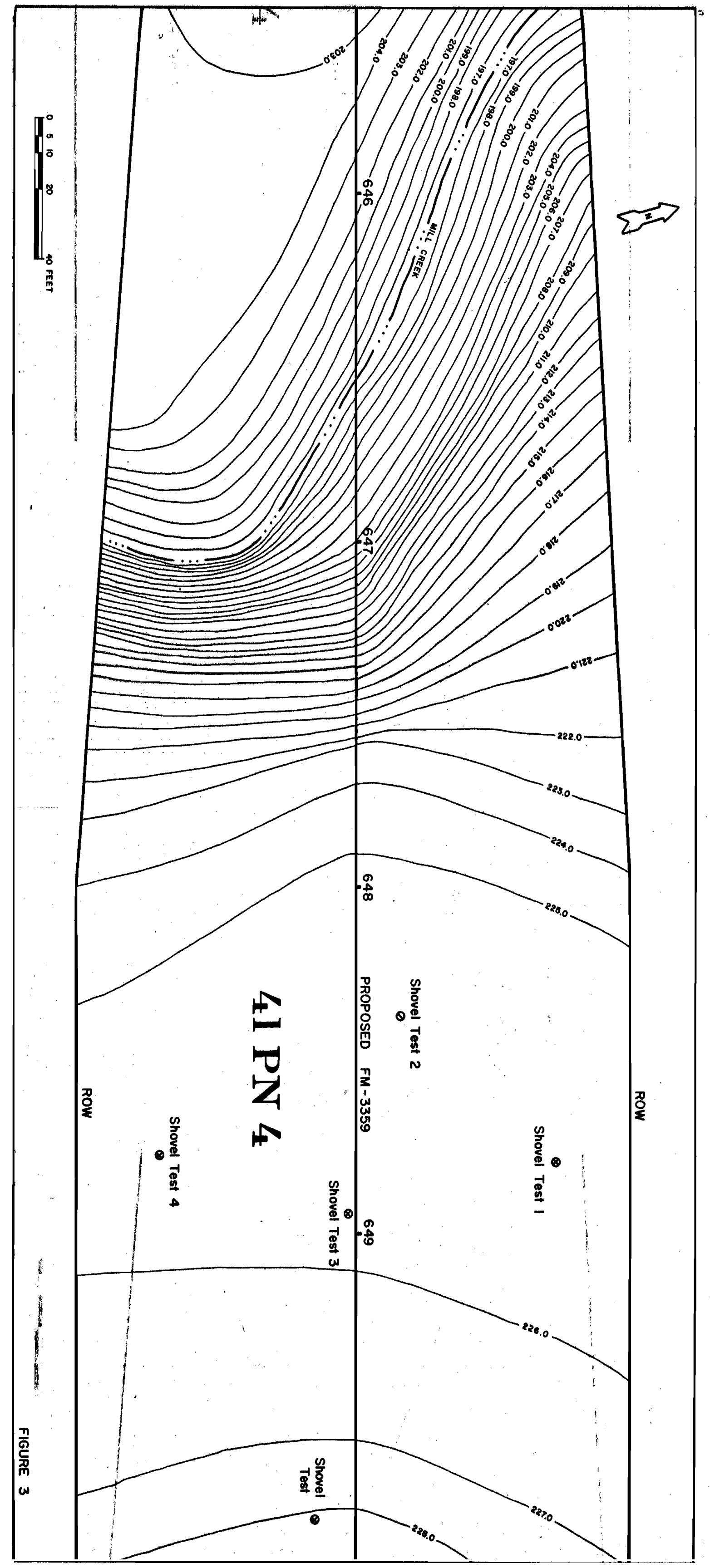


Texas. East Texas has a climatic pattern known as "summer drought"; while, for example, the Trans-Pecoa and Upper Coast climatic regions have a climatic pattern Carr (1967: fig. 3) calls "summer maximum". In the region of summer drought maximum precipitation occurs in April and $\mathrm{M}$ ay and again in November and December (Carr 1967: 8 and 17). Hot, humid summers and cool winters are the norm. These differences in general climatic patterns are due in part to physiographic considerations.

Many environmental factorshave changed since the advent of the Europeans. The ecological balance was probably upset (for a time) due to the introduction of cattle and other grazing animals; these surely constituted "an important biotic influence on vegetation complexes" (Gould 1969:9). Present day factors of cultivation, commercial timber/ logging, seeding and fertilizers have skewed our picture of the effective environment of the area's prehistoric inhabitants.

\section{ARCHEOLOGICAL BACKGROUND}

Previous Investigations

The study area is located within the geographical division of Northeast Texas. Archeologicelly it is placed within the Caddoan Area (Webb 1960:35-62). Davis(1970:27-65) and Webb(1960:35-62) both have written comprehensive, regional, archeological histories which pertain, in general, to the study aree.

Panola County has 17 recorded sites, according to the central files located at the Texas Archeological Research Laboratory at Balcones Research Center. According to the records, no sites are located within at least a 5 mile radius of 41PN3 and 41PN4, This may not be an actual indication of site density for the area; but rather, reflects a sampling bias. The other recorded sites in the county are located within 
the confines of reservoirs.

Systematic archeological investigations have been carried out on that portion of the Sabine River which has been impounded and is now called Toledo Bend Reservoir. McClurkan, et al (1966: 3) gives an account of the archeology of the area around the Toledo Bend Reservoir area as well as the McGeeBend Reservoir (Lake Sam Rayburn). He reports that both Archaic complexes and Caddoan are "well represented" with some temporally later sites in evidence. The sites in the Toledo Bend Reservoir area range in distances from 10 to 50 miles south and southeast of the present study area.

Johnson's (1962:141-284) Y arbrough and Miller sites are from 80 to 100 miles to the northwest of the present area; and along with other sites in east Texas Johnson tentatively defines the LaHarpe Aspect, an archeological complex of the Archaic stage.

Webb (1969:3-107) reported on the Resch site, about 30 miles north of 41PN3 and 41PN4. The Resch site has evidence of Middle Archaic, La Harpe Aspect and early Caddoan occupations. Also approximately 30 miles to the northwest of the study area (Martin Lake) are located sites with evidences of Archaic, "Formative Stage", and Caddoan Occupations, as well as an historic contact site (MCDonald 1962 and Clark and Ivey N.D.).

\section{MEIHODS OF INVESTIGATION}

Three methods of investigation were utilized in testing 41PN3, surface observations, excavations of chosen areas by controlled methods (3 test units), and shovel testing to reveal cultural materials, the nature of the soil and change in soil color. During excavation in 
the test squares all materials were screened through $1 / 4$ inch mesh hardware cloth and the artifacts were bagged and labeled accordingly. The existing measurement system of feet and tenths of feet was utilized. Investigative method sutilized at 41PN4 were surface observations and shovel testing.

A 11 cultural materials recovered are the property of the State of Texas. Ultimately, they are turned over to the Texas Historical Commission for disposition. All maps, photographs, field notes and other written data generated through survey and testing also will be turned over to the Texas Historical Commission for disposition.

\section{PN3}

The site is located on a small sandy knoll which runs across the right of way approximately 780 feet northwest of Mill Creek. The knoll cuts across the right of way on a northeast, southwest axis and continues for several hundred meters outside the right of way. Barbed wire fences had already been erected aa right of way boundaries at the time of testing. A bulldozer had cleared a path along the fence boundaries on each side of the right of way, Trees had been uprooted and pushed aside and the soil had been disturbed considerably. All the disturbance was within the highway right of way and no cultural materials were noticed in the disturbed areas. The site is located in a once cultivated field which at the present time is used as grazing for cattle. Vines, shrubs, and grasses grow in abundance. Near the margins of the creek and slough (which runs parallel with Mill Creek and separates 41 PN 3 into two areas), pines, cypress and some hardwoods grow, dense undergrowth abounds.

A 10-by10-foot test pit (Unit I) was situated just to the right of 
the centerline at station $638+42.77$ (Figure 2). Orientation of the test square was parallel with the centerline rather than along a north-south axis. The pit was excavated in .5 feet levels. Level 1 (surface to 207.54) of Unit I contained the following: 10 chert flakes and 5 petrified wood "flakes". None showed evidence of use or wear patterns. Level 2 (207.54-207.04) excavated to 1.0 foot below the surface contained 5 chert flakes and 3 petrified wood flakes, none were utilized.

A this point the test square was quartered and a 5 by 5 foot section excavated. A summary of the findings are as follows: Level 3 (207.04206.54) contained 9 chert flakes, 4 petrified wood flakes and 1 fragment of clear glass; Level 4 (206.54-206.04) contained 4 petrified wood flakes, 4 chert flakes and some small pieces of friable sandstone; Level 5 (206.04-205.54) Contained 1 dart point (Ellis, made of petrified wood), 1 projectile point: fragment, 21 chert flakes, 12 petrified wood flakes and 2 petrified wood cores.

The soil has a very fine sandy texture. D ue to the dry weather the soil appears very light in color and homogeneous. The underlying clay layer accounted for the only change in color and texture. Flecks of charcoal were noted sporadically throughout the excavation. No stains or other evidence of burning were noted, Since the area had once been cultivated and, given the nature of the loose soil, no context for charcoal or cultural materials was evident.

Four shovel tests were conducted on the channel easement on the right side of the right of way 300 feet to the southeast of Units II and III of 41PN3, They were approximately 1.5 feet in diameter and about 2 to 2.5 feet deep. No evidence of cultural materials were noted at all. The left side of the right of way (the channel easement area) 
had been badly disturbed by bulldozing; uprooted trees and moving of the soil had removed any original context; however, no cultural materials were noted on visual inspection of the area.

Four shovel tests were placed about 450 feet east of Unit I and about 10 feet from a dry slough on the east bank (Figure 2). They were spaced approximately 15 to 20 feet apart, across the right of way. Their general dimensions were about 2 feet in diameter and 2.5 feet deep. The soil was sandy and the upper layers contained roots of varying sizes. Three of the tests revealed no cultural materials at all. A fist-sized piece of petrified wood and a scraper or chisel-like tool of petrified wood was recovered from shovel test number 3 .

At station 642 (the general area of the last shovel tests mentioned) a 5 by 5 foot square was established (Unit II). Unit II Was parallel with the centerline and placed 5 feet "back" from Station 642 on and to the right of the centerline (Figure 2). Levels 1 and 2 (205.80-204.30) of Unit II revealed a very Sandy, homogeneous soil with many roots. Flecks of charcoal were noted but therewas no staining or darkening of soil color due to burning. One potsherd and 31 flakes of both petrified wood and chert were recovered from Level 1. Level 2 contained: 1 projectile point (possibly Ellis), projectile point fragment, 5 potsherds, 71 flakes of both petrified wood and chert. One possible petrified wood core was recovered. Some hematite and sandstonewas noted but no utilized materi als were evident. Level $3(204.3-283.8)$ continued to contain a sandy soil, a rodent burrow was encountered at this level. This level contained one projectile point of petrified wood, which could possibly be of the Gary type. Two bifaces were found and one medial section of a projectile point. 51 chert flakes were recovered along with 4 petrified wood fragments. 
Level 4 (203.8-203.3) of Unit II was made up mostly of a clayey, compact soil. The following was recovered from the last level of Unit II: 20 flakes, 7 petrified wood fragments, some sandstone and hematite pebbles.

Unit III of 41PN3 was established to the north of Unitll on the left side of the centerline $10 \mathrm{f}$ eet "back" of station 642.00 (Figure 2). The surface was cleared and Level 1 (205.8-205.3) was removed and screened through $1 / 4$ inch mesh hardware cloth. Twenty-seven flakes were recovered from the sandy soil. Levels 2 and 3 contained a total of 76 flakes and 1 core. The textured sandy soil was still in evidence. In L evel 4 (204.3-203.8) a yellowish colored clay began to show up. This level contained 35 flakes and one possible core. Level 5 (203.8-203.3) was composed of very compact clay and revealed no cultural materials although four pieces of hematite/sandstone were recovered.

Conclusions and Recommendations for 41PN3

During testing of 41PN3 no cultural materials were noted or recovered from the surface. Subsurface investigations revealed no staining or change in soil color except in the instance of natural soil layers, rodent burrows or root disturbance. No discernable features were located. There is no doubt that there was indeed occupation of the area, evidenced by recovery of some by-products of prehistoric behavior. Three dart points were recovered. They were noted to be like Ellis and Gary types. These projectile point types, according to Suhm and Jelks (1962: 187, 197) were in evidence during Archaic times. The pottery sherds recovered from 41PN3 probably place the chronological position of the site in the Archaic or Johnson's (1962) La Harpe Aspect (1ate archaic). Subsistence was more than likely still based on hunting and gathering with an emphasis on 
gathering seasonal edibles and exploiting more than one environmental zone.

The resource base for lithic tools found in the study area is local in origin. Petrified wood and mall gravels are present. Two of the projectile points are made of petrified wood, the other is made from chert. Flakes and chips of chert are small and exhibit a good deal of cortex. Flakes and chips of petrified wood occur in larger sizes and in shapes which exhibit poor flaking qualities rather than good conchoidal fracturing.

It is felt that the occupation at 41PN3 was relatively brief due to the flood prone area and the nature of the possible subsistence patterns. It is possible that the marginal area of the site is in evidence where the tests were conducted and that the more densely occupied portions are out of the right of way. It is felt that $41 \mathrm{PN} 3$ is not eligible for inclusion in the National Register of Historic Places due to the paucity of materials found and the disturbance in the area from logging and possible cultivation.

As Story (1976:46-59) points out, since initially defined, the Archaic in east Texas remains a fairly nebulous construct. Little information on this stage has come to light. 41PN3 adds little at all to that body of data. It is recommended that no further archeological work be done at $41 \mathrm{PN} 3$. However, should cultural materials, such as stone tools, pottery or bone be discovered during construction or if plans for construction out of the right of way are made, the Archeological Laboratory of the State Department of Highways and Public Transportation and the Texas Historical Commission should be notified immediately. 
41PN4

This site is located on a sandy bluff overlooking Mill Creek to the west approximately 300 feet from the county road crossing and about 825 feet from 41 PN 3 (Figure 3 ). The site is presently in woods and has been logged. During the preliminary reconnaissance of the right of way one broken biface and a few flakes were recovered. Heavy underbrush and secondary growth made ground visibility very poor. With the cooperation of the Maintenance Department in District 19, an area of approximately 50 square feet was cleared of underbrush. Upon surface inspection no cultural materials were noted. Surface observations were also made further back on the bluff, as well as shovel tests, however no cultural materials were found.

Four shovel tests were placed between stations 648.88 and 650.00, within the cleared area (Figure 3). They were each about 2 feet in diameter and 2.5 to 3 feet deep, No cultural materials were noted in the tests. One test revealed a fist-sized piece of petrified wood and another test revealed 2 pieces of ferriginous sandstone. Given the amount of material recovered during the preliminary reconnaissance and the paucity of materials recovered during testing it is tentatively stated that the occupation at 41PN 4 was an episodic event in connection with a probable hunting and/or gathering activity. Due to the history of the area, i.e., the logging that has taken place, it is felt that all context for any occupational debris has been obliterated. No information regarding function or chronological placement of the site is in hand and can only be speculated upon.

41PN4 is not felt to be eligible for inclusion on the National Register of Historic Places. No further archeological work is recommended at this 
site. However, should construction reveal any signs of stone tools, pottery or bone, the Archeological Laboratory of the State Department of Highways and Public Transportation and Texas Historical Commission be notified immediately. Should any construction be considered outside the right of way, further testing in those areas is recommended. 


\section{REFERENCES CITED}

Blair, Frank W.

1950

The Biotic Provinces of Texas. Texas Journal of

Science 2(1):98-100).

Carr, John T.

1967

The Climate and Physiography Of Texas. Report

No. 53. Texas Water Development Board. Austin.

Clark, John and James Ivey

N.D.

Archeological and Historical Investigations at Martin Lake, Rusk and Panola counties, Texas.

Researtr Report No. 32. Texas Archeological

Survey, The University of Texas at Austin.

Davis, E. Mott

1970

"Archeological and Historical Resources of the Red River Basin, Part 11-Texas". Arkansas

Archeological Survey, Publications on A rcheology

$\underline{\text { Research Series }}$ No. 1. ed. H.A. Davis.

Fenneman, Nevin M. 1938

Gould, Frank W. 1969

Texas Plants A Checklist and Ecological Summary. Texas A\&M University, Texas Agricultural Experiment Station.

Johnson, Leroy, Sr. 1962

The Yarbrough and Miller Sites of Northeastern Texas, with a Preliminary Definition of the La Harpe Aspect.

Bulletin of the Texas Archeological Society 32:141-284.

McDonald, Andrew J. 1972

An Archeological Survey of the Martin Lake Area Rusk and Panola Counties, Texas. Research Report No. 14. Texas Archeological Salvage Project, The University of Texas at Austin.

McClurkan, B. B., W.T. Field, and J. N ed W oodall 1966

Excavations in Toledo Bend Reservoir, 1964-65.

Papers of the Texas Archeological Salvage Project 8.

Story, Dee Ann 1976
"The Archaic of East Texas" in The Texas Archaic; A Symposium. Ed. T. R. Hester. Center for Archeological Research, The University of Texas at San Antonio, Special Report No. 2. 
Suhm, Dee Ann and Edward Jelks

1962

Handbook of Texas Archeology: Type Descriptions

Texas Archaological Society and the Texas Memorial

Museum, Bulletin Number 4.

Soil Conservation Service 1975

Soil Survey of Panola County, Texas, UnitedStates Department of Agriculture and the Soil Conservation Service in cooperation with Texas Agricultural Experiment Station.

Webb, Clarence 1969

The Resch Sits, 41HS16, Harrison County, Texas.

Bulletin of the Texas Archeological Society 40:3-106. 